\title{
Hubungan Indeks Massa Tubuh (IMT) dengan Kadar Apolipoprotein B (ApoB) pada Remaja Overweight dan Obes
}

\author{
${ }^{1}$ Neida V. Danun \\ ${ }^{2}$ Stefana H. M. Kaligis \\ ${ }^{2}$ Murniati Tiho
}

\author{
${ }^{1}$ Kandidat Skripsi Fakultas Kedokteran Universitas Sam Ratulangi Manado \\ ${ }^{2}$ Bagian Biokimia Fakultas Kedokteran Universitas Sam Ratulangi Manado \\ Email: neidavdanun@gmail.com
}

\begin{abstract}
Childhood obesity is one of the serious public health problems. Data from the World Health Organization in 2013 showed that about 42 million children were categorized as overweight and obese. Obesity is correlated with cardiovascular diseases. Apolipoprotein B is one of the solid predictors to diagnose cardiovascular disease in developing countries. This study aimed to determine the correlation between body mass index and Apolipoprotein B levels in overweight and obese adolescents. This was an analytical observational study with a cross sectional design. This study was participated by 23 overweight and obese adolescents. The results showed that the mean level of BMI in overweight and obese adolescents was 32 (SD \pm 4.235$) \mathrm{kg} / \mathrm{m}^{2}$, ApoB was $94,13 \mathrm{mg} / \mathrm{dL}(\mathrm{SD} \pm 19.770)$. The Spearman’s rank correlation test showed a significance level $(\mathrm{P})=0.587$ and the correlations value $(\mathrm{r})=0,120$ between body mass index and Apolipoprotein B levels. Conclusion: There was no significant correlation between BMI and ApoB in overweight and obese adolescents. Albeit, some of the overweight and obese adolescents have moderate risk to suffer from cardiovascular diseases in the future.
\end{abstract}

Keywords: body mass index, apolipoprotein B, overweight, obese, adolescents

\begin{abstract}
Abstrak: Obesitas pada anak merupakan suatu masalah serius kesehatan masyarakat. Data dari Organisasi Kesehatan Dunia (WHO) tahun 2013 melaporkan sekitar 42 juta anak yang tergolong overweight dan obesitas. Obesitas memiliki hubungan erat dengan penyakit kardiovaskular. Apolipoprotein B merupakan salah satu prediktor kuat yang dipakai negaranegara maju untuk diagnosis penyakit kardiovaskular. Penelitian ini bertujuan untuk mengetahui hubungan indeks massa tubuh (IMT) dengan kadar Apolipoprotein B pada remaja overweight dan obes. Jenis penelitian ini analitik observasional dengan desain potong lintang terhadap 23 remaja overweight dan obes. Hasil penelitian mendapatkan nilai rata-rata indeks massa tubuh pada remaja overweight dan obes $32(\mathrm{SD} \pm 4,253) \mathrm{kg} / \mathrm{m}^{2}$ dan nilai rata-rata kadar Apolipoprotein B pada remaja overweight dan obes $94,13 \mathrm{mg} / \mathrm{dL}(\mathrm{SD} \pm 19,770)$. Hasil uji korelasi Spearman mendapatkan nilai signifikan $(\mathrm{P})=0,587$ dan korelasi $(\mathrm{r})=0,120$ antara indeks massa tubuh dengan kadar Apolipoprotein B. Simpulan: Tidak terdapat hubungan antara indeks massa tubuh dengan kadar Apolipoprotein B pada remaja overweight dan obes. Walaupun demikian, sebagian remaja overweight dan obes memiliki risiko sedang terkena penyakit kardiovaskular di masa mendatang.
\end{abstract}

Kata kunci: indeks massa tubuh, apolipoprotein B, remaja, overweight, obes

Obesitas pada masa anak merupakan salah satu permasalahan serius kesehatan masyarakat saat ini. ${ }^{1}$ Data dari World
Health Organization (WHO) menunjukkan bahwa terdapat peningkatan prevalensi overweight pada anak dan remaja sebesar 
2,5\% dari tahun 1990 sampai 2010. ${ }^{2}$ Di Indonesia, berdasarkan hasil Riset Kesehatan Dasar (Riskesdas) tahun 2013 menunjukkan prevalensi gemuk pada remaja usia 16-18 tahun sebesar 7,3\% yang terdiri dari $5,7 \%$ gemuk dan $1,6 \%$ sangat gemuk (obesitas). Di Indonesia terdapat 13 provinsi dengan prevalensi gemuk di atas nasional, salah satunya ialah Provinsi Sulawesi Utara. Prevalensi gemuk pada remaja 16-18 tahun di Sulawesi Utara sebesar 3\% gemuk dan 7\% sangat gemuk. Ada 18 provinsi di Indonesia yang memiliki prevalensi obesitas sentral penduduk umur $\geq 15$ tahun di atas angka nasional, Sulawesi Utara merupakan provinsi kedua tertinggi setelah DKI Jakarta. $^{3}$

Beberapa penelitian prevalensi remaja obes di Sulawesi Utara sudah pernah dilakukan. Di Kota Bitung sudah pernah dilakukan penelitian dengan menggunakan sampel remaja di SMA Negeri 1 Bitung didapati prevalensi remaja obes sebesar 42\%. ${ }^{4}$ Penelitian lain yang dilakukan oleh Kussoy EK didapatkan prevalensi obesitas pada remaja di Kabupaten Minahasa Induk tahun 2013 sebesar 26,33\%. ${ }^{5}$ Prevalensi remaja obesitas di Kabupaten Minahasa Selatan khususnya di SMK Negeri 1 Tumpaan didapatkan sebesar 32,4\%. ${ }^{6}$ Pada tahun 2010, Kussoy DWK meneliti di Kota Tomohon didapatkan prevalensi remaja obesitas di Kota Tomohon sebear 35\%. ${ }^{7}$

Prevalensi remaja obes di Kota Bitung lebih tinggi dibanding dengan prevalensi remaja obes di Kota Tomohon, Kabupaten Minahasa Induk, dan Kabupaten Minahasa Selatan. Data-data tersebut menunjukkan bahwa masalah obesitas pada anak dan remaja di Kota Bitung saat ini menjadi salah satu masalah kesehatan yang memerlukan perhatian khusus.

Alat ukur paling umum yang digunakan untuk mendefinisikan status berat badan pada anak, remaja, dan dewasa ialah Indeks Massa Tubuh (IMT). Terdapat perbedaan kriteria perhitungan IMT pada dewasa dengan anak dan remaja dimana kriteria IMT pada anak dan remaja spesifik terhadap umur dan jenis kelamin. The Centers for Disease Control and Prevention (CDC) dan American Academy of Pediatrics (AAP) merekomendasikan penggunaan IMT sebagai skrining untuk overweight dan obesitas pada anak dari usia dua tahun. Menurut CDC (2015), dikatakan obesitas bila keadaan indeks massa tubuh (IMT) anak berada di atas persentil ke-95 dan dikatakan overweight bila keadaan IMT anak berada di atas persentil ke-85 sampai ke-95 pada grafik tumbuh kembang anak sesuai usia dan jenis kelaminnya. $^{8}$

Anak obes cenderung untuk menjadi dewasa obes. ${ }^{9}$ Obesitas pada masa anak dapat meningkatkan risiko terjadinya diabetes, hipertensi, penyakit jantung koroner, stroke, penyakit kanker tertentu, obstructive sleep apnoea, dan osteoartritis. $^{10}$ Salah satu yang termasuk pada penyakit kardiovaskuler ialah penyakit jantung koroner (PJK). Terdapat beberapa faktor risiko PJK di antaranya kadar kolesterol Low Density Lipoprotein (LDL) yang meningkat dan kadar High Density Lipoprotein (HDL) yang rendah. ${ }^{11}$

LDL dan HDL masuk dalam kelompok utama lipoprotein. Lipoprotein memiliki gugus protein yang diketahui sebagai apolipoprotein. Apolipoprotein B (ApoB) terdiri dari ApoB-100 yang disintesis di hati dan ApoB-48 yang disintesis di usus. ApoB merupakan apolipoprotein utama pada LDL. ${ }^{12}$ ApoB merupakan penanda risiko jantung yang lebih kuat dibandingkan kolesterol LDL dan triasilgliserol. ApoB digunakan dalam menentukan jumlah total partikel aterogenik. Sekarang ini di negara-negara maju telah menjadikan ApoB sebagai prediktor yang kuat untuk diagnosis penyakit jantung. ${ }^{13}$

Di Indonesia, khususnya di Bitung, penelitian kadar ApoB pada remaja overweight dan obes yang merupakan salah satu faktor risiko penyakit kardiovaskuler belum pernah dilakukan. Penelitian ini bertujuan untuk mengetahui hubungan IMT dengan kadar ApoB pada remaja overweight dan obes. 


\section{METODE PENELITIAN}

Jenis penelitian ini ialah analitik observasional dengan desain potong lintang. Penelitian ini dilaksanakan pada bulan September 2015 sampai Februari 2016 di SMA Negeri 2 Bitung dan pemeriksaan sampel darah dilakukan di Laboratorium Prodia. Populasi target penelitian mencakup remaja overweight dan obes dengan persentil $\geq 85$ usia 13-16 tahun. Populasi terjangkau ialah siswa overweight dan obes di SMA Negeri 2 Bitung yang aktif sekolah selama bulan Januari 2016. Responden penelitian menggunakan seluruh populasi yang memenuhi kriteria inklusi dan eksklusi.

\section{HASIL PENELITIAN}

\section{Karakteristik Responden}

Populasi siswa SMA Negeri 2 Bitung berjumlah 1.121 siswa terdiri dari: Kelas X 362 siswa, Kelas XI 360 siswa, Kelas XII 359 siswa, dan kelas Akselerasi 40 siswa. Dilakukan pengukuran berat badan dan tinggi badan untuk mendapatkan populasi remaja overweight dan obes yang berusia 13-16 tahun.

Hasil pengukuran berat badan dan tinggi badan mendapatkan populasi remaja overweight dan obes yang berusia 13-16 tahun di SMA Negeri 2 Bitung berjumlah 30 orang. Dari 30 orang, dua remaja sedang sakit pada saat pengambilan darah dan lima orang menolak pengambilan darah sehingga jumlah responden penelitian didapatkan sebanyak 23 orang. Karakteristik responden berdasarkan jenis kelamin dapat dilihat pada Tabel 1 dan karakteristik responden berdasarkan usia dapat diihat pada Tabel 2.
Tabel 1. Karakteristik Responden berdasarkan Jenis Kelamin

\begin{tabular}{ccc}
\hline Jenis & Jumlah & $\%$ \\
Kelamin & & \\
\hline Laki-laki & 11 & $47,7 \%$ \\
Perempuan & 12 & $52,2 \%$ \\
Jumlah & 23 & $100 \%$ \\
\hline
\end{tabular}

Tabel 2. Karakteristik Responden berdasarkan Usia

\begin{tabular}{ccc}
\hline Usia & Jumlah & $\%$ \\
\hline 13 Tahun & 1 & $4,3 \%$ \\
14 Tahun & 2 & $8,7 \%$ \\
15 Tahun & 7 & $30,4 \%$ \\
16 Tahun & 13 & $56,5 \%$ \\
Jumlah & 23 & $100 \%$ \\
\hline
\end{tabular}

\section{Indeks Massa Tubuh}

IMT responden yang berusia 13-16 tahun dikategorikan berdasarkan kurva CDC BMI-for-age growth chart. Terdapat 18 responden tergolong obesitas dan 5 responden tergolong overweight. Hasil pengukuran IMT responden dapat dilihat pada Tabel 3.

\section{Kadar Apolipoprotein B}

Merujuk pada klasifikasi kadar ApoB sebagai salah satu faktor risiko penyakit jantung yang dibuat oleh American Academy of Pediatrics, 10 orang termasuk dalam kelompok berisiko rendah (kadar Apolipoprotein B $<90 \mathrm{mg} / \mathrm{dL}$ ), 7 orang termasuk dalam kelompok berisiko menengah (kadar ApoB 90-109 mg/dL), dan 6 orang termasuk dalm kelompok berisiko tinggi (kadar ApoB $\geq 110 \mathrm{mg} / \mathrm{dL}$ ). (Tabel 4).

Tabel 3. Pengukuran IMT Responden

\begin{tabular}{ccccc}
\hline Mean & Median & Minimum & Maksimum & SD \\
\hline $32 \mathrm{~kg} / \mathrm{m}^{2}$ & $33 \mathrm{~kg} / \mathrm{m}^{2}$ & $25 \mathrm{~kg} / \mathrm{m}^{2}$ & $38 \mathrm{~kg} / \mathrm{m}^{2}$ & 4,253 \\
\hline
\end{tabular}

Tabel 4. Pengukuran Kadar ApoB Responden

\begin{tabular}{ccccc}
\hline Mean & Median & Mini-mum & Maksi-mum & SD \\
\hline $94,13 \mathrm{mg} / \mathrm{dL}$ & $91,00 \mathrm{mg} / \mathrm{dL}$ & $58 \mathrm{mg} / \mathrm{dL}$ & $135 \mathrm{mg} / \mathrm{dL}$ & 19,770 \\
\hline
\end{tabular}


Hubungan Indeks Massa Tubuh dengan
Kadar Apolipoprotein B

Uji statistik analisis bivariat yang pertama digunakan ialah uji normalitas data dengan uji Shapiro-Wilk karena jumlah responden penelitian hanya 23 orang $(<30$ responden). Hasil uji tersenut menunjukkan bahwa kedua data tersebut tidak terdistribusi normal sehingga dilakukan pengujian hubungan IMT dengan kadar ApoB menggunakan uji nonparametrik Spearman (Tabel 5).

Nilai signifikansi yang didapatkan lebih besar dari $\alpha 0,05$ yang berarti bahwa tidak terdapat hubungan bermakna antara IMT dan kadar ApoB. Gambar 1 memperlihatkan hubungan IMT dengan kadar ApoB melalui grafik simple scatter plot.

Tabel 5. Hasil Uji Nonparametrik Spearman Hubungan IMT dengan Kadar ApoB

\begin{tabular}{lcc}
\hline \multicolumn{1}{c}{ Variabel Penelitian } & $r$ & $\rho$ \\
\hline $\begin{array}{l}\text { Indeks Massa Tubuh } \\
\text { Kadar Apolipoprotein B }\end{array}$ & 0,120 & 0,587 \\
\hline
\end{tabular}

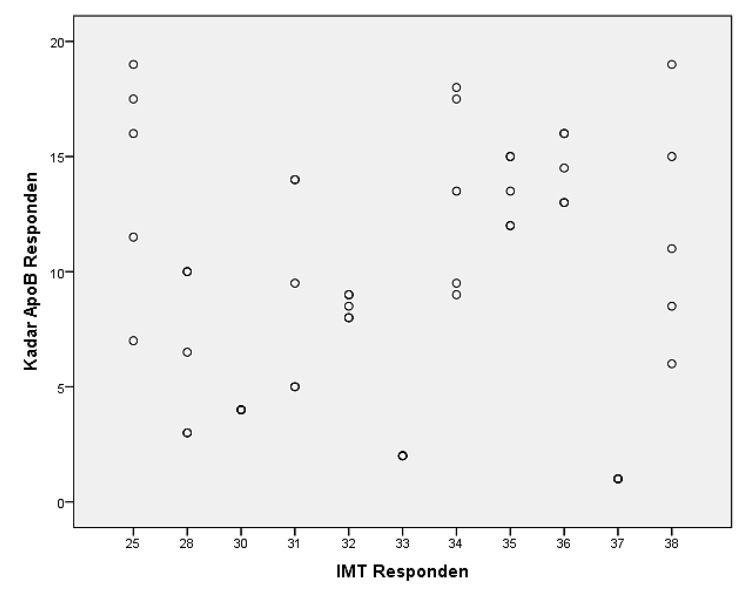

Gambar 1. Grafik simple scatter plot hubungan indeks massa tubuh dengan kadar apolipoprotein $b$

\section{BAHASAN}

Berdasarkan penelitian ini didapatkan sebanyak 18 responden (1,6\%) masuk dalam kategori obesitas dan 5 responden (0,5\%) masuk dalam kategori overweight. Pada penelitian ini didapatkan nilai persentase obesitas sama dengan penelitian yang dilakukan pada remaja Portugal oleh Fonseca et al. $^{14}$ yag mendapatkan nilai persentase obesitas 1,6\%. Pada studi lain dengan karakteristik subjek yang sama yaitu remaja berusia 14-17 tahun yang dilakukan oleh Cahyani ID ${ }^{15}$ di Denpasar, didapatkan nilai persentase obesitas mencapai 2,8\%.

Pada penelitian ini didapatkan nilai persentase overweight lebih rendah dibandingkan penelitian yang dilakukan oleh Fonseca et al. (14,4\%) dan Cahyani ID $(7,8 \%){ }^{14,15}$ Hal ini dapat disebabkan oleh karena jumlah responden penelitian yang lebih sedikit dibandingkan dengan kedua penelitian tersebut.

Pada penelitian ini didapatkan rata-rata kadar ApoB pada remaja overweight dan obes 94,13 mg/dL. Berdasarkan klasifikasi kadar ApoB untuk anak dan remaja yang dikeluarkan oleh American Academy of Pediatrics, nilai rata-rata kadar ApoB responden berada dalam rentang kadar normal yaitu 90-109 mg/dL. Nilai rata-rata kadar ApoB dalam penelitian ini sedikit lebih tinggi dari nilai rata-rata kadar ApoB pada penelitian Glowinska B et al. ${ }^{17}$ dengan subjek anak dan remaja obes usia 14 tahun yang mencapai 86,2 mg/dL. Berbedanya hasil penelitian yang didapatkan peneliti dapat disebabkan oleh karena pada penelitian yang dilakukan oleh Glowinska et al. terdapat 49 anak dan remaja berusia 14,3 tahun yang obes sedangkan pada penelitian ini hanya 18 anak dan remaja berusia 13-16 tahun yang termasuk dalam kategori obesitas.

Obesitas dapat meningkatkan kadar LDL karena terjadi penimbunan lemak di jaringan adiposa sehingga asam lemak meningkat yang kemudian merangsang produksi triasilgliserol sehingga terjadi peningkatan sekresi LDL dalam darah. ${ }^{18,19}$ Peningkatan kadar LDL dalam darah dapat memengaruhi kadar ApoB karena komponen protein terbesar dari LDL dan Very Low Density Lipoprotein (VLDL) merupakan ApoB. ${ }^{20}$

Berdasarkan hasil uji statistik dengan uji nonparametrik Spearman, IMT dengan kadar ApoB pada remaja overweight dan 
obes tidak memiliki hubungan yang bermakna. Hal ini berbeda dengan penelitian yang dilakukan oleh Nageswara et al. ${ }^{21}$ pada 296 anak sekolah di India yang berusia 10-17 tahun dimana kadar serum ApoB menunjukkan korelasi positif dengan IMT. Kadar ApoB menunjukkan peningkatan pada anak-anak yang overweight dan obes, yaitu 88,54 $\pm 11,4$ $\mathrm{mg} / \mathrm{dL}$ pada anak obes dan $82,6 \pm 12,64$ $\mathrm{mg} / \mathrm{dL}$ pada anak overweight. Penelitian yang dilakukan oleh Spinneker et al. ${ }^{22}$ pada 1076 remaja berusia 12,5-17,49 tahun di Eropa, menunjukkan adanya korelasi positif antara IMT dan kadar Apo B.

Teori-teori dan penelitian-penelitian di atas membuktikan bahwa IMT dan kadar Apo B memiliki hubungan yang bermakna, tetapi terdapat banyak faktor yang bisa memengaruhi hasil yang didapat. Pada penelitian ini didapatkan tidak terdapatnya korelasi antara IMT dan kadar Apo B dapat disebabkan jumlah responden yang kecil (<30 sampel) dibandingkan dengan jumlah responden pada penelitian-penelitian sebelumnya yang mencapai lebih dari 200 responden. Faktor lain yang dapat memengaruhi hasil yang didapat peneliti antara lain data yang tidak terdistribusi normal.

Limitasi penelitian ini antara lain ialah jumlah responden penelitian yang hanya mencapai $76,7 \%$ dari seluruh populasi yang dapat memengaruhi sebaran data.

\section{SIMPULAN}

Berdasarkan hasil penelitian dan bahsan dapat disimpulkan bahwa tidak terdapat hubungan antara indeks massa tubuh dengan kadar Apolipoprotein B pada remaja overweight dan obes. Walaupun demikian, sebagian remaja overweight dan obes memiliki risiko sedang terkena penyakit kardiovaskular di masa mendatang.

\section{SARAN}

1. Penyuluhan kepada responden mengenai pola hidup sehat yakni berolahraga secara teratur dan makanan yang mengandung gizi seimbang.

2. Pemberian informasi untuk menjaga Indeks Massa Tubuh tetap dalam batas normal.

\section{DAFTAR PUSTAKA}

1. Centers for Disease Control and Prevention. About BMI for children and teens. [cited 2015 Sept 19]. Available from: http://www.cdc.gov/healthyweight/asse ssing/bmi/childrens_bmi/about_childre ns_bmi.html

2. World Health Organization. Global Database on Child Growth and Malnutrition. [cited 2015 Sept 21]. Available from: http://www.who.int/nutgrowthdb/publi cations/overweight_obesity/en/

3. Badan Penelitian dan Pengembangan Kesehatan Kementrian Kesehatan RI. Riset Kesehatan Dasar 2013. [cited 2015 Sept 22]. Available from: http://www.depkes.go.id/resources/dow nload/general/Hasil\%20Riskesdas\%20 2013.pdf

4. Bonde JY. Prevalensi Hiperurisemia Pada Remaja Obesitas di SMA Negeri 1 Kota Bitung [Skripsi]. Manado: Universitas Sam Ratulangi; 2011.

5. Kussoy EK, Fatimawali, Kepel B. Prevalensi Obesitas pada Remaja di Kabupaten Minahasa. Jurnal ebiomedik. 2013;1:981-5.

6. Kumaat G. Prevalensi Hiperurisemia pada Remaja Obesitas di SMK Negeri 1Tumpaan Kabupaten Minahasa Selatan [Skripsi]. Manado: Universitas Sam Ratulangi; 2011.

7. Kussoy DWK. Prevalensi Hiperurisemia pada Remaja Obesitas di Kota Tomohon [Skripsi]. Manado: Universitas Sam Ratulangi; 2010.

8. Sarah A. Hubungan Indeks Massa Tubuh dengan Tekanan Darah Anak di Sekolah Dasar Negeri 064979 Medan [Skripsi]. Medan: Universitas Sumatera Utara; 2013.

9. Anonim. Obesitas. In: Marcadante KJ, Kliegman RM, Jenson HB, Behrman RE, editors. Ilmu Kesehatan Anak Esensial. Ikatan Dokter Anak Indonesia, alih bahasa. Jakarta: Ikatan Dokter Anak Indonesia, 2011; p.122-3.

10. World Health Organization. Global Status 
Danun, Kaligis, Tiho: Hubungan indeks massa...

Report on Noncommunicable Diseases 2014. [cited 2015 Sept 24]. Available from:

http://apps.who.int/iris/bitstream/10665 /148114/1/9789241564854_eng.pdf?ua $=1$

11. Adam JMF. Dislipidemia. In: Sudoyo AW, Setiyohadi B, Alwi I, Simadibrata MK, Setiati S, editors. Buku Ajar Ilmu Penyakit Dalam (5th ed). Jakarta: Interna Publishing, 2009; p. 1984-7.

12. Botham KM, Mayes PA. Pengangkutan dan Penyimpanan Lipid. In: Murray RK, Granner DK, Rodwell VW, editors. Biokimia Harper (27th ed). Pendit BU, alih bahasa. Jakarta: EGC, 2009; p. 225-9.

13. Nurulita A. Perbandingan Kadar Apolipoprotein B dan Fraksi Lipid Sebagai Faktor Resiko Sindrom Koroner Akut [Skripsi]. Makassar: Universitas Hasanudin; 2011.

14. Fonseca H, de Matos MG. Perception of Overweight and Obesity among Portugese Adolescent: an overview of associated factors. Eur J Public Health. 2005;15(3);323-8.

15. Cahyani ID. Prevalensi Berat Badan Berlebih Dan Obesitas Dan Hubungannya Dengan Nilai Akademis Pada Remaja Kelas Sepuluh SMA Negeri 1 Bangli Tahun 2012 [Skripsi]. Denpasar: Universitas Udayana; 2012.

16. Keseimbangan Diet; Aturan Pemberian makanan; Obesitas dan Kelaparan; Vitamin dan Mineral. In: Guyton AC, Hall JE, editors. Buku Ajar Fisiologi
Kedokteran (11th ed). Jakarta: EGC, 2007; p. 917-8.

17. Glowinska B, Urban M, Koput A, Galar M. Selected new Atherosclerosis Risk Factors in Obese, Hypertensive and Diabetic Children and Adolescents. NCBI. 2003;167(2):275-86.

18. Cholesterol Absorption, Synthesis, Metabolism, and Fate. In: Smith C, Marks A, Lieberman M. Mark's Basic Medical Biochemistry (2nd edition). Philadelphia: Lippincott Williams \& Wilkins, 2005; p. 633-9.

19. Botham K, Mayes P. Sintesis, Transpor, dan Eskresi Kolesterol. In: Murray RK, Granner DK, Rodwell VW, editors. Biokimia Harper (27th ed). Pendit BU, alih bahasa. Jakarta: EGC, 2009 ; p. 248-9.

20. Gaw A, Murphy MJ, Cowan RA, O'Reilly D, Stewart MJ, Shepherd J. Biokimia Klinis (4th ed). Mahode AA, Manurung J, alih bahasa. Jakarta: EGC, 2012; p. 130-1.

21. Nageswara S, Gurumurthy P, Sruti E. Role of Serum Apolipoprotein Levels Indian Children And Adolescents. IJBPS. 2013;4(1):(B)387-394.

22. Spinneker A, Egert S, Gonzáles-Gross M, Breidenassel C, Albers U, StoffelWagner B, et al. Lipid, Lipoprotein and Apolipoprotien Profiles in European Adolescents And Its Associations With Gender, Biological Maturity and Body Fat-The HELENA Study. Eur J Clin Nutr. 2012; 66(6):727. 